Regular Article

pISSN: 2287-2396, eISSN: 2287-240X

Journal of Forest Science

Vol. 29, No. 4, pp. 292-299, November, 2013

http://dx.doi.org/10.7747/JFS.2013.29.4.292

\title{
Ecotourism Carrying Capacity and the Potentiality of the Safari Park of Bangladesh
}

\author{
Kazi Mohammad Masum ${ }^{1, *}$, Abdullah Al Mamun², Zahed Mohammad Malekur Rahman³, Md. Motlubur Rahman ${ }^{3}$, \\ Md. Shah Newaz ${ }^{5}$ and Mohammad Redowan ${ }^{1}$ \\ ${ }^{1}$ Department of Forestry and Environmental Science, Shahjalal University of Science and Technology, Sylhet-3114, Bangladesh \\ ${ }^{2}$ Department of Environment, Bangladesh \\ ${ }^{3}$ Bangabandhu Sheikh Mujib Safari Park, Cox's Bazar-4743, Bangladesh \\ ${ }^{4}$ Department of Forest, Bangladesh \\ ${ }^{5}$ Institute of Forestry and Environmental Sciences, University of Chittagong, Bangladesh
}

\begin{abstract}
The study was undertaken to assess the tourist's carrying capacity and to explore ecotourism potential of Bangabandhu Sheikh Mujib Safari Park, the only safari park of Bangladesh. Carrying capacity was assessed both from physical and social aspect. On the other hand, 250 visitors were interviewed with semi structured questionnaire for ecotourism prospect evaluation along with some secondary data. The total daily-allowed visit was 17,300 with rotation coefficient of 3.46 . Maximum daily average numbers of tourists were relatively below the physical carrying capacity of the Park $(5,000)$. The social carrying capacity was 4.38 persons per day. As there are different categories of visitors, their choice of encounters and number of expected encounters also varied. Each year, the total tourist's number varied significantly $(\mathrm{p} \leq 0.05)$. That proved the safari park had immense tourist prospect. 85 percent visitors were from lower and middle class family as entrance fees and other fees inside were very cheap in relation to other private amusement place. The ecological perspective of the park will remain unaltered if the carrying capacities of the area are followed with sustainability. Therefore, it is the proper time for taking appropriate decision.
\end{abstract}

Key Words: carrying capacity, ecotourism, tourism prospect, wildlife safari, Bangladesh

\section{Introduction}

Ecotourism is the fastest growing industry in the present world. Today almost every country both developed and developing realizes the economic and social importance of ecotourism and has been constantly striving to get as much share of its benefits (Sultana 2001). The protected areas without physical exploitation can generate more revenue in the form of improvement of climate, purification of water and air, storage and supply of fresh water, flood control, biodiversity conservation, tourism and local community devel- opment (Lwin 1999). Being a land of easy grace and of mellow fruitfulness, Bangladesh is one of the best spots for the tourist of the world (Chowdhury 2002).

The maximum number of visitors may visit a tourist destination at the same time, without causing destruction of the physical, economic, socio-cultural environment and an unacceptable decrease in the quality of visitors' satisfaction (UNEP 1998). The carrying capacity concept offered the useful strategy for reaching a desired end applicable to decision facing managements. In a planning or environmental management context, carrying capacity has been defined as

Received: November 7, 2012. Revised: August 28, 2013. Accepted: August 30, 2013.

Corresponding author: Kazi Mohammad Masum

Department of Forestry and Environmental Science, Shahjalal University of Science and Technology, Sylhet-3114, Bangladesh

Tel: 88-01816052842, Fax: 88-0821-713491, E-mail: kmmasum-for@sust.edu 
the ability of a natural or man-made system to absorb population growth without significant degradation (Schneider 1978). Such research was largely done in wilderness settings where it was hypothesized that increasing levels of contact could produce large reductions in visitor satisfaction (Lucas and Priddle 1964).

Carrying capacity can be subdivided into physical (physically accommodation), ecological (limit up to unacceptable or irreversible decline in ecological values) and social (maximum level of recreational use upto which decline in the quality of the recreation experience) (Pigram 1983). Calculation of physical carrying capacity should serve as a starting point from which the assessment of overall recreational carrying capacity can proceed (Wilkinson 1995). As the amount of space in areas is fixed, the only opportunity to increase physical capacity will lie in the development of management parameters aimed at more complete or efficient utilization (Shelby and Heberlein 1984). A corollary of this principle is that there is no one inherent carrying capacity of a park or tourist attraction. Rather, each park or tourist attraction (or even site within such an area) has a range of capacities depending upon the degree of resource protection and type of visitor experience to be provided. Management considerations include zoning, engineering, interpretation, and persuasion used as tools for predicting the impact of visitors on recreation areas (Wagar 1964).

The concept of a tourism or Recreation carrying capacity evolved from a neo-Malthusian perspective of resource limitations. The concept also carries a number of assumptions that are unsupported in the real world. A variety of planning frameworks, such as Visitor Experience and Resource Protection and Limits of Acceptable Change have been developed to address issues of visitor impact ( $\mathrm{McC}$ ool and Lime 2001).

Recent textbooks and articles (Saveriades 2000) reflect this interest and have suggested that destinations not be developed beyond their saturation points or 'innate capacities' for tourism. For these Saveriades (2000) and others writers, planners and scientists prescribed to specify numerical capacities to ensure that the environment, tourism experiences and the social fabric community do not suffer unwanted consequences. If degradation occurs, then management action is implemented to return the area to within its numeric carrying capacity. By effectively reducing the complex set of issues associated with tourism development to a scientifically determined 'magic number', advocates of carrying capacity promise that technological solutions will be appropriate.

Yet, recent attempts to develop actual carrying capacities (e.g. Brown and Turner 1997; Saveriades 2000) in terms of specific numbers of tourists or visitors, raise significant questions for the decision-makers that experiences the effects of tourism. Price (1999) summarised a variety of research on carrying capacity by stating it as a self validating belief and flawed matter. Other authors have raised additional arguments about the practical utility of carrying capacity and its scientific foundations (Dhondt 1988; Mcleod 1997). No single capacity can be assigned to an entire area (Lime 1970). They suggested that social capacity appeared to be a function of visitor motivations and expectations.

The concept of carrying capacity is one, which exemplifies the need to maintain development and activities at a level that is both ecologically and socially sustainable and activities beyond which environmental degradation occurs (Getz 1982; Hovinen 1982). Wildlife itself is often the victim of tourist development. As well as suffering a loss of habitat, where tourist facilities and road are constructed wildness is affected, in other ways, by the influx of tourist to their regions (Seddighi and Shearing 1997). While providing an enjoyable experience in nature the fundamental functions of ecotourism are protection of natural area, production of revenue education and local participation and capacity building (Pedersen 1991). Finally, it should be noted that the concept of carrying capacity of parks and related tourist attractions has been controversial. Carrying capacity has been variously characterised as 'slippery' (Alldredge 1973), 'elusive' (Graefe et al. 1984) and 'illusive' (Becker et al. 1984). Moreover, carrying capacity might be addressed most effectively through identification of indicators and standards of quality. Monitoring of indicator variables would ensure that standards of quality are not violated (Manning et al. 1996).

Bangabandhu Sheikh Mujib Safari Park possesses a magnificent natural beauty, fascinating landscape where lofty Garjan (Dipterocarpus spp.)trees with close canopy presents in a bushy scattered and depressions. This protected area is considered as one of the richest hotspot in Bangladesh. Tourists here are increasing day by day. The 
park was set up with the motto of providing conservation, promoting ecotourism and socio economic upliftment of the adjacent community. Thus, the present study was undertaken to assess the status of carrying capacity and the recreational and ecotourism potentialities of the park for realization and future planning. The programme of research described in this paper raises a number of issues regarding estimation and management of carrying capacity of parks and related tourist attractions. In fact there was no such work regarding carrying capacity and ecotourism potential of safari park in Bangladesh perspectives.

\section{Methodology}

Bangabandhu Sheikh Mujib Safari Park is located on previously declared reserve forest land of Fashiakhali Foest Range of Forest Department in Chakaria Upazilla, under Cox'sBazar District, Bangladesh established in 1996. It is situated beside the Chittagong-Cox'sBazar Highway, 47 $\mathrm{km}$ north of Cox's Bazar town. The safari park was chosen purposively due to its good reputation for tourist's service. The studied area lies between $21^{\circ} 43^{\prime} \mathrm{N}-21^{\circ} 56^{\prime} \mathrm{N}$ latitude and between $91^{\circ} 50^{\prime} \mathrm{E}-92^{\circ} 23^{\prime} \mathrm{E}$ longitudes (Fig. 1). Reconnaissance survey was done for better understanding followed by literature collected from Institute of Forestry and Environmental Sciences, University of Chittagong (IFESCU) library and Central library of University of Chittagong. Relevant secondary information on ecotourism and recreation facilities of the study area has been gathered from previous official records of the Forest Department, Review Papers, Journals, Books, Magazines and other recent publications and Internet (Fig. 1).

Intensive care was taken regarding the applicability, reliability and validity of the collected information. Data and relevant information for recreational development of the safari park was collected through semi structured group interviews with visitors. Total 250 tourists were interviewed from the tourist. 250 visitors were chosen randomly from all over the park to avoid biasness. The field study was conducted over a period of 6 months (from July 2011 to December 2011). The time of the research was from $9.0 \mathrm{am}$ to $1.30 \mathrm{pm}$ and 2.30 to $5.30 \mathrm{pm}$. In defining the carrying capacity of the safari park the definitions of Pigram (1983), Shelby and Heberlein (1984) were used. Moreover, help taken from the formula developed by Boullon (1985).

$$
\text { Physical Carrying capacity }(P C C)=\frac{\text { Area used by tourists }}{\text { Average idividual standard }}
$$

The Area Used by Tourists is the actual measurement in sq. meter, of the space that can possibly be occupied by visitors. The Average Individual Standard is totally depending on the decision of management and planners. This may be 2 sq. $\mathrm{m}$ to 10 sq. $\mathrm{m}$. depending on the considerations such as space for movement, disturbance each person and noise, nature of the place etc. Here, the calculation based on 2 sq. $\mathrm{m}$. The total number of allowed daily visits is then obtained:

\section{Total of Daily Visits $(T D V)=$ Carrying Capacity $\times$ Rotation Coefficient}

The rotation coefficient is thus determined:

Rotation Coefficient $(R C)=$

No. of Daily hours the area is open to Tourists

Average Time of Visit

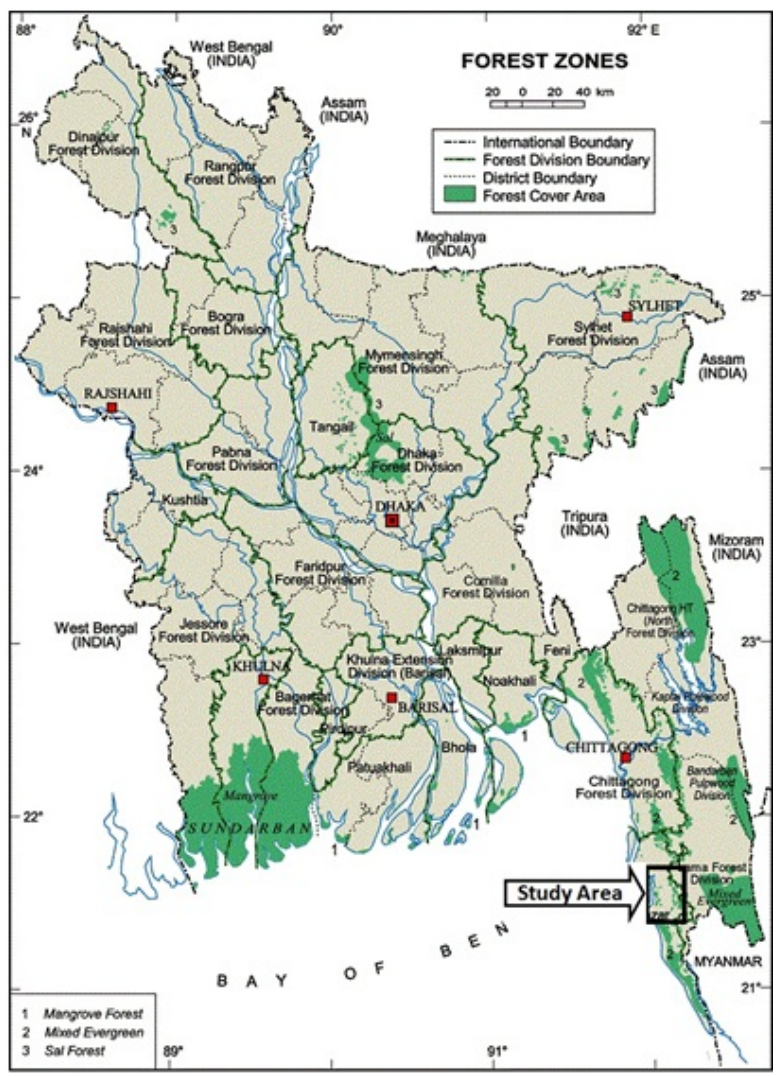

Fig. 1. Map of Bangladesh showing the study area. 
Social carrying capacity assessed by the definition by Pigram (1983). The maximum level of recreational use, in terms of numbers and activities, above which there is a decline in the quality of the recreation experience from the point of view of the recreation participant. Finally ANOVA test were made to test the significance of variables.

\section{Results and Discussion}

\section{Carrying capacity}

For the proper administrative and management purpose or facilitation of development works, determination of carrying capacity of a protected area like safari park is urgent. This research is one of the problem-oriented researches that may occur in the near future. Physical Carrying Capacity (PCC) of the park was determined as 5,000 persons (Tourists) by using the Boullon's (1985) formula. The Average Individual Standard was counted as average of normal human private space and the limit of increase for the visitors was found as 2 square metres and 10 square metres respectively. The safari park is opened for the tourists 9 hours/day and the average time staying at the park was 2.6 hours. The rotation co-efficient of the daily visit was obtained as 3.46 and the total number of allowed daily visit was calculated as 17,300 persons (Tourists). If any factor is subject to change, it obviously moderate the carrying capacity figure in a whole. Actually it is one of the primary works on PCC in any tourist place of Bangladesh. Therefore, available data regarding this matter is very scarce.

The study revealed that the Social Carrying Capacity on an average was 4.38 persons (Table 1). Social Carrying Capacity creates the lower bound; while, physical carrying capacity creates the upper bound. It was observed that maximum number of expected varied with the social status and nature of the visitors. The study revealed that during the visiting time, maximum allowable encounters expected by friends was 5 , which were 4 for the family, educational group and individual visitors and 3 for the couples (Table $1)$.

Ali (2008) reported the same experience at Banskhali Eco-park, Chittagong, Bangladesh. The composition of the tourists indicated that a group of friends formed the major portion $(44 \%)$ of the total tourist visiting the park fol-
Table 1. Maximum allowable encounters to different visitor groups in the study area

\begin{tabular}{lcc}
\hline Category of visitor & $\begin{array}{c}\text { Visitors } \\
\text { expectation of } \\
\text { encounters }\end{array}$ & $\begin{array}{c}\text { Weighted expected } \\
\text { encounters of visitor }\end{array}$ \\
\hline Group of friends (44\%) & 5 & $220 \%$ \\
Group of families (39\%) & 4 & $156 \%$ \\
Educational group (6\%) & 4 & $24 \%$ \\
Individuals (5\%) & 4 & $20 \%$ \\
Couple (6\%) & 3 & $18 \%$ \\
Total (100\%) & 20 & $438 \%$ \\
Average & 4 & 4.38 \\
\hline
\end{tabular}

lowed by the family group from different places (39\%) (Table 1).

\section{Ecotourism potentiality}

\section{Number of tourists visiting the safari park}

According to the United Nations World Tourism Organization (UNWTO), International tourist arrivals increased from 25 million to 903 million from 1950 to 2011 . International tourist arrivals in 2011 increased with a growth of $6.6 \%$ as compared to 2010 . Our tourist season is in winter i.e. October to March when there is a extreme cold in Europe and America and the tourist spots are not favourable for visiting. We are also in a favourable position from lengthy tourism season here. Our tourism industry has an extra advantage in terms of location too. All the tourist location is situated within a distance of 400 kilometres from the capital Dhaka (Uddin 2009).

The longest sea beach is situated just $40 \mathrm{~km}$ away from the safari park. So safari park was getting tourist attention. Table 2 states that Tourists were significantly varied each year. In summer tourists numbers were varied significantly than in winter. Actually, winter (November to February) is the main tourist season in Bangladesh. Rainy season is very unusual season for tourist. In summer (March to June), environment is flexible. Therefore, tourist fluctuation is different.

South African nature based tourist varied with high significance which has increased dramatically in the last decade. Actually South Africa is famous for tourist destination. During the period of last decades their advertisement and their international fames rose up (Uddin 
2009). On the other hand, Bangabandhu Sheikh Mujib Safari Park is a flagship unit initiated as a trial basis. Banskhali Eco-park, Chittagong, Bangladesh experienced $84 \%$ tourist at winter where as $5 \%$ tourist at rainy season (Ali 2008). In that sense safari park is providing tourist facility for all season (Table 2 ).

\section{Age-class distribution of tourist in safari park area}

Table 3 states that young visitors ( $\leq 30$ years) got three times higher (72\%) interest in tourism than aged person. Young peoples are always very enthusiastic and like to take endeavour. Therefore, their participation is normally high in tourism. Surprisingly $11.2 \%$ of the visitors were over 40 years of old category. It represents that safari park provides mental amusement for all ages (Table 3).

Weaver (2002) observed a significant difference between the two groups in terms of gender distribution among the Australian ecotourists where $73 \%$ of the hard-core cluster being female, compared with $62 \%$ of all other ecotourists. This approximates to the study by Weiler and Richins (1995) on Earth watch participants, where $69 \%$ of whom

Table 2. Number of tourists visiting the Safari Park in different seasons

\begin{tabular}{lrrrr}
\hline \multirow{2}{*}{ Year } & \multicolumn{4}{c}{ Total number of tourist visiting in different } \\
& \multicolumn{4}{c}{ season } \\
\cline { 2 - 5 } & Winter & Summer* & Rainy & Total* \\
\hline 2009 & $1,03,978$ & 11,590 & 20,902 & $1,36,470$ \\
2010 & $3,31,101$ & 67,300 & 50,900 & $4,49,301$ \\
2011 & $4,28,200$ & 71,100 & 60,903 & $5,60,203$ \\
Total & $8,63,279$ & $1,49,990$ & $1,32,705$ & \\
Yearly average & $2,87,760$ & 49,997 & 44,235 & \\
Monthly average & 57,552 & 24,998 & 22,118 & \\
Daily average & 1,918 & 833 & 737 & \\
\hline
\end{tabular}

*Indicates significant different at $\mathrm{p} \leq 0.05$. were female. But Bangabandhu Sheikh Mujib Safari Park detects the higher male visitor $(56.8 \%)$ than female (43.2\%). Infact Bangladeshi Social norms doesn't favorable for women for outing. Hard-core ecotourists are also significantly younger than other ecotourists in Australia.

\section{Income level of visitors}

The study revealed that maximum visitors (48\%) come from medium family followed by low-income family (37\%) and rich family (15\%). actually 85 percent visitors come from lower and middle class family (Table 4). As it is government owned, forest department operated protected area, entrance fees, other fees were very cheap in relation to other private amusement place. Therefore less income visitors got their interest. Sultana (2001) reported it as a common phenomenon in all over government owned Eco-park, National park, Zoos etc (Table 4).

\section{Frequency of visit in the wildlife safari}

Weaver (2002) reported that 59\% of expenditure of Australian tourist was on ecotourism, compared with $42 \%$ for other ecotourists. While this indicates a higher level of engagement with ecotourism though it does not reveal whether these expenditures occurred on specialized as opposed to multipurpose trips. Ecotourism is a new concept in Bangladesh. Moreover organized ecotourist places are few

Table 4. Income level of visitors in the Park Area

\begin{tabular}{lc}
\hline \multicolumn{1}{c}{ Category } & $\begin{array}{c}\text { Visitors } \\
\text { percentages }\end{array}$ \\
\hline Low income family (3,000-5,000 BDT*/month) & $37 \%$ \\
Medium income family (5,001-9,000 BDT/month) & $48 \%$ \\
Rich family** (Above 9,000 BDT/month) & $15 \%$ \\
\hline
\end{tabular}

*Bangladeshi Taka/Currency (BDT). **Foreign visitors included into the Rich family member.

Table 3. Age-class distribution of tourist in Safari Park area

\begin{tabular}{lcccccccc}
\hline & $<10$ years & $11-20$ years & $21-30$ years & Sub total & $31-40$ years & $41-50$ years & $>50$ years & Sub total \\
\hline Male & 23 & 28 & 51 & 102 & 24 & 9 & 7 & 40 \\
Female & 18 & 91 & 39 & 78 & 18 & 6 & 6 & 30 \\
Total & 41 & 49 & 90 & 180 & 42 & 15 & 13 & 70 \\
$\%$ & 16.4 & 19.6 & 36 & 72 & 16.8 & 6 & 5.2 & 28 \\
\hline
\end{tabular}


in number. From the study it was found that out of 250 visitors, $94 \%$ visited the study area for the first time while $6 \%$ visited the area for the second time. Therefore, it can be said that as an ecotourism potential the Bangabandhu Sheikh Mujib Safari Park is now in exploring stage. It was also explored that different visitors visited for different purposes. Out of 250 visitors in the study area $9 \%$ came for sight seeing, $89 \%$ came for recreation and just $2 \%$ without specific reasons.

\section{Duration of stay}

Weaver (2002) revealed that expenditures and trip duration expenditure estimates are usually characterized by a high degree of error but are still useful in providing an approximation of consumer behaviour and economic impact.

The study indicated that most of the tourists (78\%) stay at the safari park for 2 hours followed by 4 hours (Couple) and 3 hours (educational group). Therefore the average stay by the tourists at the park is 2.6 hours. The composition of the tourists indicated that group of friends formed the major portion (44\%) of the total tourists visiting the Park followed by the family group from different places (39\%). Study showed that students from different institutions were $(6 \%)$ followed by couple group (6\%). Number of individual tourist was found only $5 \%$ of the total tourists (Table 5).

\section{Level of satisfaction by the visitors}

Fig. 2 depicts the satisfaction level of the visitors. Though $38 \%$ tourists were highly satisfied, $15 \%$ were completely unsatisfied. Ali (2008) sketched the same scenario of visitor satisfaction level at Banskhali Eco-park. Actually, these tourists were not satisfied due to over expectation. Moreover, they had seen some foreign safari park and start-

Table 5. Duration of Stay by the tourists in Safari Park

\begin{tabular}{lc}
\hline \multicolumn{1}{c}{ Visitors category } & Duration of stay in hours \\
\hline Educational $(6 \%)$ & $3 \mathrm{hrs}$. \\
Individual (5\%) & $2 \mathrm{hrs}$. \\
Friend group (44\%) & $2 \mathrm{hrs}$. \\
Family group (39\%) & $2 \mathrm{hrs}$. \\
Couple (6\%) & $4 \mathrm{hrs}$. \\
Total $(100 \%)$ & $13 \mathrm{hrs}$. \\
Average & $2.6 \mathrm{hrs}$. \\
\hline
\end{tabular}

ed to compare with them. To establish the real ecosystem of a safari park, it needs a lot of time and money. This park only passed its 8 years. So it would be unusual to expect more from it. Satisfaction level depicts the upliftment of its status (Fig. 2).

\section{Impact of ecotourism activities}

Tourist perceptions regarding the development works on vegetation, natural environment, infrastructure and socio-economic environment were assessed in the research work. $66 \%$ tourist took it very positively stating that the development works did not hamper those elements. 5.13\% disagreed by telling it mostly affected the elements. These visitors were true nature lover. They believed that any operation in forest means disturbing the nature. But to make it easy to all ladders of visitors, some development works were necessary. Majority portion loved it (Table 6).

\section{Problems identified by tourists}

Though the recreational activities were not hampered, the interviewed visitors identified some problem for the better management of the park in present or future. Sound pollution (26\%) got the top most priority followed by bench shortage (25\%), toilet limitation (18\%), parking (17\%) and accommodation (14\%). actually during the research work, vehicles were allowed in the park. so there was some sound pollution. Demands of the visitors were so high that limited resources couldn't fulfil the desire.

\section{Conclusion}

The increasing public interest in nature and landscapes is considered today a major positive factor in the process of

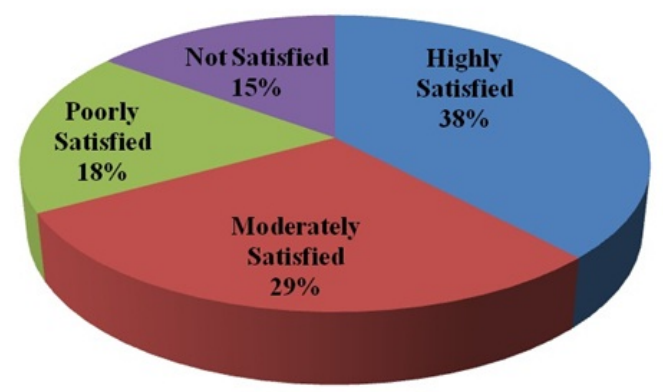

Fig. 2. Level of satisfaction by the visitors in the study area. 
Table 6. Impact of ecotourism activities on Safari Park

\begin{tabular}{lcccc}
\hline \multirow{2}{*}{ Elements } & \multicolumn{3}{c}{ Percentage of respondents considering different impacts } \\
\cline { 2 - 5 } & Mostly affected & Moderately affected & Least affected & Not considerably affected \\
\hline Vegetation & 1.00 & 3.13 & 2.13 & 18.75 \\
Natural environment & 4.13 & 5.25 & 3.13 & 12.75 \\
Infrastructure & 0.00 & 4.13 & 3.13 & 17.75 \\
Socio-economic environment & 0.00 & 4.13 & 4.13 & 16.75 \\
Total & 5.13 & 16.64 & 12.52 & 66.00 \\
\hline
\end{tabular}

conservation and wise use of ecologically sensitive and important areas. On the contrary, the growing influx of visitors may exert strong pressures on fragile ecosystems and lead to their degradation with a consequent loss of biodiversity. The environment of the park is being polluted by non degradable polythene rappers, solid waste, soft drink and mineral water cans etc which are brought by visitors. However, the erecting of the boundary wall all around the park will cut off the terrestrial wild animals to travel into or pass though this site, it will save some valuable species from extinction. Still now, the impact of ecotourism development activities on recreational as well as conservation of natural phenomena of this protected area is very much positive but it may turn about.

\section{References}

Alldredge R. 1973. Some capacity theory for parks and recreation areas. Trends 10: 9-20.

Ali M. 2008. Ecotourism Development Opportunities in Bangladesh: an Empirical study on Chunati Wildlife Sanctuary. MBA thesis. University of Science and Technology Chittagong (USTC). Chittagong, Bangladesh, pp 87.

Boullon RC. 1985. Planificacion del Espacio Turistico. Trillas, Mexico, pp 23-31.

Becker RH, Jubenville A, Burnett GW. 1984. Fact and judgement in the search for a social carrying capacity. Leisure Sciences 6: 475-486.

Brown K, Turner HK. 1997. Environmental carrying capacity and tourism development in the Maldives and Nepal. Environmental Conservation. 24: 25-316.

Chowdhury K. 2002. Ecotourism: Dimensions of Sustainability. In: Ecotourism for Forest Conservation and Community Development: Proceedings of an International Seminar, held in Thailand, 28-31 January 1997 (Bornemeier J, Victor M, Durst PB, eds). RECOFTC, FAO, Bangkok, Thailand, pp 14-25.

Dhondt AA. 1988. Carrying capacity: a confusing concept. Acta
Oecologia 9: 337-346.

Getz D. 1982. A rationale and methodology for assessing capacity to absorb tourism. Ontario Geography 19: 92-102.

Graefea AR, Vaskea JJ, Kussa FR. 1984. Social carrying capacity: An integration and synthesis of twenty years of research. Leisure Sciences 6: 395-431.

Hovinen GR. 1982. Visitor cycles: Outlook for tourism in Lancaster County. Annals of Tourism Research 9: 565-583.

Lime DW. 1970. Research for determining use capacities of the Boundary Waters Canoe area. Naturalist 21: 9-13.

Lucas RC, Priddle GB. 1964. Environmental perception: A comparison of two wilderness areas. Annals of the Association of American Geographers, Syracuse, New York, pp 23-31.

Lwin UT. 1999. Ecotourism Development in Myanmar. Tiger Paper 27: 6-13.

Manning RE, Lime D, Hof M. 1996. Social carrying capacity of natural areas: Theory and application in the US National Parks. Natural Areas Journal 16: 118-127.

McCool SF, Lime DW. 2001. Tourism Carrying Capacity: Tempting Fantasy or Useful Reality? Journal of Sustainable Tourism 9: 372-389.

Mcleod SR. 1997. Is the concept of carrying capacity useful in variable environments? Oikos 79: 529-542.

Pedersen A. 1991. Issues, problems and lessons learned from eco-tourism planning projects. pp 6174.

Pigram JJ. 1983. Outdoor Recreation and Resource Management. St. Martin's Press, New York, pp 262-271.

Price D. 1999. Carrying capacity reconsidered. Population and Environment 21: 5-26.

Saveriades A. 2000. Establishing the social carrying capacity for tourist resorts of the east coast of the Republic of Cyprus. Tourism Management 21: 147-156.

Schneider DM, Godschalk DR, Axler N. 1978. The Carrying Capacity Concept as a Planning Tool. American Planning Association, Chicago, pp 33-38.

Seddighi HR, Shearing DF. 1997. The demand for tourism in North East England with special reference to Northumbria: an empirical analysis. Tourism Management 18: 499-511.

Shelby B, Heberlein TA. 1984. A Conceptual Framework for Carrying Capacity Determination. Leisure Sciences 6: 433-451. 
Sultana IZ. 2001. Tourism Industries in Bangladesh and World Tourism Day 2001. The Bangladesh Observer Weekend Magazine, Dhaka. September 28. pp 3-6.

Uddin A. 2009. Country Branding Promoting Tourism in Bangladesh. Current Affairs 151: 40-41.

UNEP. 1998. Ecolabels in the Tourism Industry. UNEP, Nairobi, Kenya, pp 34-38.

Wagar J. 1964. The Carrying Capacity of Wild Lands for
Recreation. Forest Science 7: 1-25.

Wilkinson T. 1995. Crowd control. National Parks 69: 36-41.

Weaver DB. 2002. Hard-core Ecotourists in Lamington National Park, Australia. Journal of Ecotourism 1: 19-35.

Weiler B, Richins H. 1995. Extreme, extravagant and elite: Aprofile of ecotourists on Earthwatch expeditions. Tourism Recreation Research 20: 29-36. 